\title{
Career Advancement of Female Accountants in Accounting Professional Practice in Nigeria
}

\author{
Adetula Dorcas, Nwobu Obiamaka, Owolabi Folashade \\ Department of Accounting, Covenant University, Ota, Ogun State, Nigeria \\ Department of Accounting, Covenant University, Ota, Ogun State, Nigeria \\ Department of Accounting, Covenant University, Ota, Ogun State, Nigeria
}

\begin{abstract}
The purpose of this study is to examine the factors affecting career advancement of female accountants in accounting professional practice in Nigeria. The study also adopts a survey research design. Even though the study covers the population of accountants in professional practice in Nigeria, a sample of a hundred (100) qualified and non-qualified accountants including male and female was selected purposively from the big four accounting firms in Lagos State, Nigeria. The research instrument used is the questionnaire. The data collected was analyzed using chi-square. It was discovered that family responsibilities do not affect career advancement of male and female accountants. Also, the findings revealed that gender does not influence the access of accountants to opportunities within the job. Finally, it was deduced that gender influences the choice of continuity of accountants in the professional practice of accounting. It is recommended that accounting firms should provide female accountants with more flexible work schedules.

Keywords: Career Advancement, Female Accountants, Accounting, Professional Practice, Nigeria.
\end{abstract}

\section{Introduction}

Organizations such as the United Nations, Organization for Economic Co-operation and Development and the World Bank are paying more attention to women. Accounting is not just about financial statements; it is about organizational skills which women also possess (Ramdhony, Oogarah-Hanuman and Somir, 2012). The study of the history of women has shown that women occupied positions of varying importance in various societies. The development of women may be described as epileptic because their roles were defined by strong cultural values which today still seem to be struggling against the tide of change (Sani, 2001). Originally, the presence of females in the accounting profession in Nigeria was very rare, with only one female accountant recognized by the Institute of Chartered Accountants of Nigeria (ICAN) in 1965. While this was the case in Nigeria, it is getting better with more female accountants going into professional practice. There has been a dearth of these females in top positions in accounting firms. Internationally, there has been similar evidence as Ramdhony, Oogarah-Hanuman and Somir (2012) found that the analysis of the gender ration in the three big accounting firms of Mauritius show that there is an under representation of women accounting professionals in senior positions.

Female accountants may not be able to advance in their career because their responsibility to their family conflicts with their career goals. Women are usually expected to be primarily responsible to their family before anything else. Consequently, a good woman in our society is measured by her ability to put all aside and care for her family. Thus the assumption holds that women who have families are not always committed to the job. Emergency family demands can distract her attention on the job. Some employers also have the opinion that the woman will not be able to stay long hours on the job. This perception is what mainly brings about female stereotyping in the workplace.

Some researchers have traced inadequate career advancement of female accountants in professional practice to inadequate access to opportunities within the job such as training and development, mentoring and networking. These opportunities are crucial for career advancement because through them the accountant is exposed to business contacts, and people are able to appreciate the services of the accounting firm. Women are also not adequately represented in leadership positions in the profession. This is evidenced by the fact that since 1960 up till date, the Institute of Chartered Accountants in Nigeria (ICAN) has had a total of four (4) female presidents.

The rest of the paper is divided into five sections. Section two briefly reviews relevant and related literature on career advancement of female accountants, while section three addresses the research methodology employed. Section four presents the data analysis, results and discussion; while the last section contains a summary of research findings and the concluding part of the paper. 


\section{Literature Review}

Since 1965 when the Institute of Chartered Accountants in Nigeria (ICAN) registered the first female accountant, the number of females entering the profession has substantially increased (Institute of Chartered Accountants of Nigeria Membership Handbook), Similarly in a neighboring West African country, Ghana, there has been steady increase in the number of females admitted into the Institute of Chartered Accountants Ghana (Bruce-Twum, 2013). For many women, the reason for this entry into the workplace is to provide financially for their family and aid their career development. Vincoli (2005) noted that during World War II, the number of women entering the accounting profession boomed as firms wanted to replace the vacancy left by the men who went to war. When the soldiers returned many women had to vacate those professional positions for the men. Subsequently, there was a period of depression in the world economy that led to decreased birth rates. Due to the bad economic situation, many women did not give birth to children during this period. This gave women the chance to continue working.

The general perception about women is that they are less devoted to a firm because of maternity leave and a woman who has children will not return to work (Trigg, Nabanji and Onifade, 1997). This implies that a man has an advantage over a woman in this light. Moreover, women have domestic responsibilities which may inhibit their full participation in building their career to the top. The need to look into gender issues in the accounting profession cannot be overemphasized because of the changes the $21^{\text {st }}$ century has brought in the area of female participation in developing her career. Sesay and Odebiyi (1998) observed that women are responding to changes around them. More so, they are even looking for ways to improve themselves. Crawford and Unger (2004) posited that women's increased participation in paid work has been one of the strongest social trends of the past 30 years. Despite this, women in the accounting profession may not be rising as expected.

Work may be described as labor that brings income. It can also be described as something that takes place outside the home for pay (Bird and Meville, 1994). Similarly, work can be defined as an activity that produces something of value for other people (Neubeck and Neubeck, 1997). Mostly, women work outside the home to support the finances of their family. Reasons why women may be found in the workplace are financial security, self development and improvement of self-worth through acquisition of skill. Lauer and Lauer (2004a) identified that increased financial power may make marriage more equitable and provide a sense of security. Crawford and Unger (2004) noted that women's position in the workplace is not just a static aspect of social life. It is continuously recreated as people make workplace decisions based on gender. Thus, as women are given the opportunity to carry out job responsibilities, they are able to perform and get promoted when the time comes.

There are particular attitudes associated with the female gender known as stereotypes. They affect the way the people perceive the abilities of the woman and how they feel women should perform. D'Angelo (1994) noted some of the cultural attitudes that affect women in the practice of accounting which are inability to cope with stress, preference for men workforce and inability to stand pressure when there is a lot of work. These impede the progress of female leaders (Lips, 2003). Stereotypes are further encouraged when women are deemed as unfit for a particular position of authority because of their sex, their responsibility of motherhood and organizational policies pertaining to their welfare is not clearly spelt out.

Freeman (1995) also discovered that when the majority of those in a profession are of one sex, the normative expression develops fast that this is how it should be. The model of the practitioner then takes on the personality and behavioral characteristics associated with that dominating sex. Furthermore, Lauer and Lauer (2004:180b) described this stereotype in the "damsel in distress and white knight of folklore illustrating the longstanding notion that men are the independent and women are the dependent creatures". Consequently, women may not occupy equal positions with men even in professions.

An individual involved in the professional practice of accounting is one who works in an accounting firm that renders services like auditing, tax management, forensic accounting, management consultancy and other financial expert services to the public. It also includes one who has an accounting firm. Only members of the Institute of Chartered Accountants of Nigeria (ICAN) are entitled to practice as accountants in Nigeria (ICAN Membership Handbook, 2002). Before license is given to practice in the profession, the individual must have undergone some training for 30 months in a recognized accounting firm in Nigeria or abroad. Professional practice jobs are usually entry-level jobs that lead up the organizational ladder.

Based on the pipeline theory (Wulson and Moyes, 1998), women enter into the lower end of the pipeline in the accounting profession with the expectation of rising to the top but they are not able to emerge at the top of the 'pipeline'. Consequently, the women who have reached the top positions in professional practice are few in number and this condition may be traced to stereotyping in the workplace. Bird and Meville (1994:245) noted that "a career is not just a professional or managerial job, but a parallel path to their domestic lives, a place where they gain financial independence, recognition, respect and a separate identity". It is a succession of professional positions that require more skill acquired through on-the-job training, each related to 
the next. Baker and Monks (1996) examined the effect of family responsibilities on career advancement. Other factors influencing career advancement are access to information through mentoring and networking (Baldiga, 2005; Vincoli, 2005; Twomey, Linehan and Walsh, 2002).

Work-family conflict has been found to exist as pressures from work and family roles are mutually exclusive (Twomey et al, 2002). Wulson and Moyes (1998) also concurred that work and family are mutually exclusive. Therefore, a major concern for majority of accounting professionals is work/life balance (Baldiga, 2005). In similar view, Barker and Monks (1996) discovered that for women to reach the top in the accounting profession, combining the responsibilities of a long term relationship with career plans will be difficult. Equally, Burn (2005) noted that the real and perceived responsibilities of women to home and family may prevent upward mobility in their career. Perhaps, commitment to work may be impaired as they are responsible to their families (Borgia, 1989). In response, accounting firms are offering career breaks and part-time work and this trend will be useful to women who want to enjoy successful careers while raising a family (Ramdhony, Oogarah-Hanuman and Somir, 2012). Abidin, Penafort, Jusoff and Marzuki (2008) has advocated that overtime hours that are inevitable during peak periods can be reduced by recruiting more staff. However, this has cost implications for the organization in terms of salary and bonus.

In the words of Bird and Meville (1994) most management and executive careers command complete loyalty and submission into corporate structure. It is characterized by the rigidity of deadlines which are not flexed to accommodate family and personal schedules. The woman encounters a situation where there is divided attention on the job. The cost of investment and training of employees is high. Hence, losing them is a loss to the accounting firm. It is for this reason that some accounting firms are taking steps to provide more family friendly work environments by introducing flexible and compressed work schedules.

Another factor that contributes to career advancement is access to mentorship. Role models or mentors can be described as members of one's own reference group who are visibly successful (Carwford and Unger, 2004). It also occurs when a senior organizational member helps guide a junior member by sharing knowledge about how to succeed in an organization (Burn, 2005). Experiences of the expert are then used by the new comer in making decisions. It provides an opportunity where questions are asked and the mistakes other persons have made are avoided.

Interestingly, there are fewer women in top professional positions than men (Loughlin, 1999). This increases the probability that a female accountant may not be mentored by top colleagues. In the same vein, Trigg, Nabangi and Onifade (1997) cited Baldiga (1994) and concurred that mentors provides women with access to clients and develop business relationships. Unfortunately, some males may not be favorably disposed to women entering certain professions (Maupin, 1993 as cited in Trigg, Nabangi and Onifade, 1997). Similarly Bruce-Twum (2013) noted that even though there was a steady increase in the number of females admitted into membership of the Institute of Chartered Accountants Ghana every five years, none of the women in the study sample was in the top hierarchy of their respective jobs.

Networking is another factor that contributes to career advancement. They are informal settings where men from different walk of life, exchange business and other ideas. However, they may have a damaging effect on the careers of women (Twomey et al, 2002). Their study also revealed that at "senior levels of management the glass ceiling intensifies as networks and the men's club becomes increasingly important in facilitating further progress". Freeman (1995) argued that the exclusion of women from male networks can marginalize them in the sense that when such important professional decisions as selection for promotion, research grants and departmental privileges are under consideration.

\section{Research Method}

This study utilized a survey research design. The data used in this study were mainly primary retrieved by means of copies of questionnaire which were administered to three hundred (300) accountants in professional practice. These accountants were selected from the Big four accounting firms in Nigeria. Seventy five copies of the questionnaire were administered to each professional accounting firm. The questionnaire was made up of many closed and few open-ended questions consisted of four parts.

\section{Findings}

A total of two hundred and four (204) responded to the survey, yielding 68 percent response rate. The demographic details are shown in Table 1 below.

Table 1

\begin{tabular}{|l|l|l|}
\hline Sex & Frequency & Percentage \\
\hline Male & 147 & 72.1 \\
\hline Female & 57 & 27.9 \\
\hline Total & 204 & 100.0 \\
\hline
\end{tabular}

Source: Administered Questionnaires 
The two hypotheses were tested using t-test. The result of the t-test applied on the first hypothesis revealed that there is a significant difference in the advancement of female and male accountants in Professional Practice in Nigeria (see Table 2 below).

Table 2 Present Position

\begin{tabular}{|l|l|l|l|}
\hline Response & Female & Male & Total \\
\hline Trainee & 20 & 43 & 63 \\
\hline Associate & 50 & 90 & 140 \\
\hline Senior & - & 1 & 1 \\
\hline Total & 70 & 134 & 204 \\
\hline
\end{tabular}

Administered Questionnaires

Also, the t-test applied on the second hypothesis revealed that there is a significant difference in the scores for male and female accountants with respect to the influence of family responsibilities on Professional Practice (see Table 3 below).

Table 3

\begin{tabular}{|l|l|l|l|}
\hline Response & Female Respondents & Male Respondents & Total \\
\hline Yes & 27 & 26 & 53 \\
\hline No & 5 & 4 & 9 \\
\hline Total & 32 & 30 & 62 \\
\hline
\end{tabular}

Source: Administered Questionnaires

The results revealed that the calculated chi-square is 0.066 for 1 degree of freedom at 0.05 level of significance. This is less than the table value of chi-square at the same degree of freedom and level of significance.

Also, from the results we deduced that gender and opportunities within the job (mentoring and networking) are unrelated (see Table 4 below).

Table 4

\begin{tabular}{|l|l|l|l|}
\hline Respondents & Yes & No & Total \\
\hline Female & 30 & 2 & 32 \\
\hline Male & 27 & 3 & 30 \\
\hline Total & 57 & 5 & 62 \\
\hline
\end{tabular}

Source: Administered Questionnaires

The results revealed that the calculated value of chi-square is 0.589 for 1 degree of freedom and at 0.05 level of significance. This is less than the table value of chi-square at the same degree of freedom and level of significance.

Interestingly, gender affects the decision to continue the professional practice career (see Table 5 below).

Table 5

\begin{tabular}{|l|l|l|l|}
\hline Respondents & Female & Male & Total \\
\hline Very Sure & 18 & 23 & 41 \\
\hline Indifferent & 14 & 7 & 21 \\
\hline Total & 32 & 30 & 62 \\
\hline
\end{tabular}

Source: Administered Questionnaires

The results revealed that the calculated value of chi-square is 2.882 for 1 degree of freedom at 0.05 level of significance. This is higher than the table value of chi-square at the same degree of freedom and level of significance.

Overall, the findings of this study are in contrast with the findings of Burn (2005:114) who discovered that real and perceived responsibilities of women to home and family may prevent upward mobility in the organization. In contrast with the findings of this study, Loughlin (1999:11) found that women may not have access to such opportunities such as training and development on the job that enhances career development. Finally, the third finding was similar to that held by Lips (2005:519) that although men have tended to enter the workplace and continue employment until they retire, women's participation used to show a sharp decline during childbearing years, followed by a rise as women whose children are grown returned to work. Thus, we can conclude that the choice to continue in the professional practice is gender biased.

\section{Conclusion}

This research illustrates that advancement for the female accountant in a professional practice career may not be inhibited by family responsibilities and opportunities within the job such as mentoring and networking. However, the choice to continue in the profession is gender biased. Even though the findings revealed that family responsibilities and career advancement are unrelated, some factors such as stress and 
career satisfaction were not looked into by this study. Also, the findings revealed that women are not limited in access to mentoring and networking opportunities within the job. The choice to however continue in the profession was positive by the male gender. This illustrates that women may have a different opinion of their aspiration in the professional practice of accounting. That is unlike men they do not aspire top positions in the profession. Perhaps, this can be attributed to factors such as stress, inadequate satisfaction and stereotyping.

It is envisaged that the study will contribute meaningfully towards the future studies in career advancement of female accountants in professional practice. The analysis provided in the study will provide information on the factors that need to be expounded upon in future studies. There is need for women to aspire to greater heights in the profession to enhance their visibility in the top echelons of the accountancy profession. Future studies on career progression of female accountants in professional practice may look into the area of stereotyping. This is because this creates the glass ceiling that prevents the upward mobility of persons in the workplace. Future studies may also look into reasons why women do not foresee continuing in professional practice of accounting.

\section{References}

[1]. Abidin, Z.Z., Penefort, F., Jusoff, K. and M. Marzuki (2008). Impediments to Women Accountants' Career Progression in Malaysia. Asian Social Science. Vol. 4, No. 10. pp 159-174.

[2]. Baldiga, N.R. (2005). Opportunity and Balance: Is Your Organization Ready to Provide Both? Journal of Accountancy. Retrieved 18/02/2009,fromhttp://www.journalofaccountancy.com/Issues/2005/May/OpportunityAndBalancelsYourOrganiz ationReadyToProvideBoth.htm

[3]. Baker, C.P. and K. Monks (1996). The Glass Ceiling: Cracked but not Broken? Evidence from a Study of Chartered Accountants. DCUBS Research Papers. No. 1. Retrieved 18/02/2009, from http://www.dcu.ie/dcubs/research_papers/no1.html

[4]. Bird, G. and N. Meville (1994). Families and Intimate Relationships. London: McGraw Hill.

[5]. Borgia, C. R. (1989). Promoting Women CPAs (Certified Public Accountants): An Analysis of the Report of the Upward Mobility of Women. The CPA Journal Online. Retrieved 18/02/2009, from http://www.luca.com/cpajournal/old/15499675.htm

[6]. Bruce-Twum, E. (2013). The Accounting Profession and the Female Gender in Ghana. Accounting and Finance Research. Vol. 2, No. 1. pp 54-60

[7]. Burn, M.S. (2005). Women Across Cultures: A Global Perspective. New York: McGraw Hill.

[8]. Crawford, M. and R. Unger (2004). Women and Gender: A Feminist Psychology. New York: McGraw Hill

[9]. D'Angelo, D. (1994). Family Issues to Shape the Profession's Future. The CPA Journal Online. Retrieved 18/02/2009, from http://www.luca.com/cpajournal/old/15499675.htm

[10]. Freeman, J. (1995). Women: A Feminist Perspective. California: Mayfield Hill.

[11]. Institute of Chartered Accountants of Nigeria (ICAN) Membership Handbook 2002

[12]. Lauer, R.H. and J. Lauer (2004a). Social Problems and the Quality of Life. Boston:McGraw Hill.

[13]. Lauer, R.H. and J. Lauer (2004b). Marriage and Family: The Quest for Intimacy. Boston: McGraw Hill

[14]. Lips, H.M. (2003). A New Psychology If Women: Gender, Culture and Ethnicity. New York: McGraw Hill.

[15]. Loughlin, S. (1999). Barriers to Women's Career Progression: A Review of the Literature.Working Paper No. 6. Retrieved from www.ssc.govt.nz.

[16]. Neubeck, K.J. and M.A. Neubeck (1997). Social Problems: A Critical Approach. Boston: McGraw Hill.

[17]. Ramdhony, D., Oogarah-Hanuman, V. and N. Somir (2012). Career Progression of Women in Accounting- The Case of Mauritius. International Conference on Applied and Management Sciences (IAMS'2012), Bangkok. Retrieved 02/10/2013, from http://psrcentre.org/images/extraimages/612025.pdf

[18]. Sani, H. (2001). Women and National Development: The Way Forward. Ibadan: Spectrum Books Ltd.

[19]. Sesay, A. and A. Odebiyi (1998). Nigerian Women in Society and Development. Ibadan: Dokun Publishing House.

[20]. Trigg, R.R., F.K. Nabangi and E.O. Onifade (1997). Women in the Public Accounting Profession. Academy of Accounting and Financial Studies Journal. 1(2). Retrieved 17/02/2009, from http://www.alliedacademies.org/Publications/Journals/aafsj12.pdf

[21]. Twomey, A., M. Linehan and J.S. Walsh (2002). Career Progression of Young Female Accountants: An Evidence from the Accountancy Profession in Ireland. Journal of European Industrial Training.

[22]. Vincoli, A. (2005). An Analysis of the Progression of Women in the Accounting Profession. UNC Journal of Student Research in Accounting. No. 2

[23]. Wulson, F. R. and A. D. Moyes (1998). Gender Differences among Certified Public Accountants. The Nigerian Accountant. 